\title{
O percurso de uma pesquisa em História
}

\author{
The route of a research in History
}

\section{Maria Siqueira Santos ${ }^{1}$}

\section{RESUMO}

Esse texto é o relato da pesquisa que empreendi quando realizava o curso de Mestrado em História Social na Universidade Estadual de Londrina. Iniciei a pesquisa estudando o romance Nove noites de Bernardo Carvalho, embrenhei-me pelo labirinto de suas vozes narrativas e envolvi-me na discussão a respeito de sua metaficcionalidade. Em seguida, analisei teses acadêmicas que focalizavam tais metaficções. Queria visualizar o discurso acadêmico acerca da literatura contemporânea, perceber se tais trabalhos poderiam ser classificados como metaficcionais. Ao ler as teses, porém, descobri António Lobo Antunes. Autor de vários romances, esse português começou sua produção literária com Memória de elefante, cuja trama se desenrola ao longo do dia de um psiquiatra que encontra na linguagem a possibilidade de transformar o mundo. Quando pensava finalmente ter encontrado minha fonte histórica, um episódio casual, o encontro com um livro, mudou a direção de minha pesquisa. Escrito pelo filósofo Peter Sloterdijk, $A$ árvore mágica conta a história do magnetismo animal; é "uma tentativa épica com relação à filosofia da psicologia."

O presente texto, por ser um relato do percurso da pesquisa de fontes, termina no momento em que descobri esse romance e pude delimitar o assunto a ser tratado em meu texto dissertativo.

Palavras-chave: História cultural. Linguagem. Pesquisa historiográfica. Literatura. Magnetismo animal.

${ }^{1}$ Mestre em História Social pela UEL. Trabalho dissertativo parcialmente financiado pela Capes. 
This article problematizes what high school students (14-19 years old) think about history and his teaching in a virtual space. From Orkut, virtual network of relationships, investigates virtual communities related to the discussion of the history and his teaching, privileging the comments posted on forums (place to debates about the subject). Discusses the nature of the virtual sources and justifies its use as material for historical research. Considers the new ways of thinking about the reality and construction of identity/community of the subject who experiences cyberculture and after this, highlights the significance that netizens place on history and his teaching, in particular the "practicality" of this field of knowledge and/or school discipline.

This text is the reporting of the research that I undertook while realizing the Mastering course in Social History in the State University of Londrina. I started the research studying the novel Nove noites written by Bernardo Carvalho, then I penetrate into the labyrinth of its narrative voices and got involved in the discussion about its metafictionality. Then I analyzed some academic theses that focus those metafictions. I would like to visualize the academic discourse about contemporary literature, realize if these works could be classified as metafictions. As I read the theses, however, I discovered António Lobo Antunes. Author of several novels, this Portuguese began his literary production with Memória de Elefante, which plot unfolds throughout the day of a psychiatrist that finds in language the possibility of transforming the world. For when I thought I had finally found my historical source, a sudden episode, the encounter with a book, changed the direction of my research. Written by the philosopher Peter Sloterdijk, $A$ árvore mágica, tells the story of the animal magnetism; it is "an epic attempt in relation to the philosophy of psychology."

For being a report of the route of the research of my sources this text goes up to the moment that I discovered Sloterdijk' s novel and could delimit the subject of my dissertation.

Keyword: Cultural history. Language. Historical research. Literature, animal magnetism.

\section{Preparativos da viagem}

Quando viajo de trem, gosto de observar a paisagem que vai passando. Ou seria melhor dizer que gosto de observar a paisagem que vai ficando, pois quem passa é o trem, sou eu, que ocupo um lugar em um de seus vagões, é o tempo. Tempo para observar a paisagem. Corre o trem, pairam os pensamentos. Conforme o trajeto é percorrido o ambiente muda e os elementos de minha observação se transformam: outros tipos de árvores, variados grupos de pássaros, rios de diversos tamanhos e profundidade, plantações, variação climática, do solo. Ao recepcionar com os meus sentidos toda essa diversidade do mundo que vai passando, percebo, também com os meus sentidos, que em mim algo se metamorfoseia e, assim como Teleco, o coelhinho de Murilo Rubião, encarno o mito grego 
de Proteu$_{1}{ }^{2}$ com a diferença que de dentro do trem não posso prever o futuro. Nem mesmo consertar o passado.

A viagem como metáfora para descrever o percurso de uma pesquisa é bastante apropriada, pois tanto a primeira quanto a segunda apresentam três variantes constantes: 0 tempo, a distância e a vivência. Quando uma pessoa faz uma viagem, ela percorre um determinado trajeto durante um determinado tempo. Isso também acontece com uma pesquisa. Para começar o trabalho, o pesquisador ${ }^{3}$ escolhe o local de onde dará início a sua viagem, ou seja, elabora a sua questão primordial, seleciona seu ponto de partida. Assim ele faz, porém, diferentemente do viajante, sem sequer imaginar onde e quando chegará ao seu destino. Conforme trilha os caminhos da pesquisa, o historiador presencia também a transformação que vai se operando nos elementos da paisagem.

No caso de uma investigação historiográfica, os elementos da paisagem são metáforas para as fontes históricas. Cada livro, cada filme, cada imagem, enfim, cada objeto cultural que chega às mãos do pesquisador e passa por sua leitura interage com ele, modifica-o e, além disso, torna-se mais um elemento que forma o percurso da pesquisa, mais um estímulo na composição de sua vivência. Em cada caminho, uma árvore, em cada fonte, uma referência ao passado. A imagem que o viajante vê da janela do trem é fugidia, assim também é provisória a verdade linguística a respeito do passado a que chega o historiador. Se a viagem é uma metáfora para a pesquisa e os elementos da paisagem para as fontes, o trem é uma metáfora para a vida. O viajante está onde está o trem, portanto, ele só pode ver aquilo que passa, a cada momento, por sua janela. Ele não vê mais o que passou nem vê ainda o que virá. No entanto, pode lembrar-se do que viu e imaginar o que chegará. Assim também ocorre com o historiador que, inserido em seu tempo presente, não pode decifrar o passado nem prever o futuro. Entretanto, pode se ocupar das memórias do que já foi e vislumbrar, com sua imaginação histórica, tanto um (passado) quanto outro (futuro).

O historiador está onde está a vida, do presente não pode escapar. Basta-lhe, por isso, escancarar sua janela para o instante e, inspirado e guiado por uma experiência artística de vida, elaborar uma descrição autêntica sobre o passado a partir de sua imaginação histórica. Porque a verdade da história, disse sabiamente o greco-moderno Johann Goethe, não passa de uma "verdade subjetiva" . Por criar o mundo de acordo com

\footnotetext{
2 Proteu, deus marinho, o 'velho do mar' ; filho dos titãs Tétis e de Oceano (alguns afirmam que seu pai foi Poseidon). Possuía o dom de adivinhação e, por isso, era procurado pelas pessoas que queriam saber a respeito do futuro. Para avaliar se essas pessoas estariam aptas a ouvir a resposta, Proteu metamorfoseava-se em monstruosos seres marinhos. Se o humano enfrentasse o perigo, Proteu lhe contava o futuro. Outra maneira de fazê-lo falar sobre o destino era prendê-lo enquanto dormia. Há notícias de que foi assim que Menelau, rei de Esparta, conseguiu fazê-lo revelar o resultado da guerra de Troia. (DUGNANI; CRUZ, 2007).

${ }^{3}$ Essa metáfora pode ser utilizada para qualquer tipo de pesquisa, no entanto, nesse trabalho, o pesquisador em questão é alguém que transita no campo da historiografia e é comumente chamado de 'historiador' .
} 
sua própria ideia, o historiador-artista poderá “[...] representá-lo perfeita e completamente" , não precisará se ocupar em "[...] construir o seu mundo de tal forma que caibam todos os fragmentos que a história nos transmitiu [...]" , pois tal narrativa objetiva não passará de um heróico esforço de pesquisa, compilação, emenda e cola de acontecimentos (GOETHE apud WERNET, 1980, p. 148-149).

O fato é que, ao longo de minha pesquisa, conforme entrava em contato com as fontes históricas, ou melhor, com os discursos linguísticos que são essas fontes, envolvia-me tão profundamente com cada uma delas que fui metamorfoseando-me enquanto pesquisava. Parti como Teseu, levando um novelo para desenrolá-lo ao longo do caminho, então, virei Ariadne e segui as pistas deixadas pelo herói para, enfim, transformar-me em Minotauro. Meu fio condutor nesse labirinto das palavras escritas: a literatura.

Novas perguntas, outras relações, novas paisagens foram configurando-se em minha mente e instigavam-me a continuar pesquisando, lendo, expandindo o campo do meu conhecimento sobre assuntos diversos que poderiam ser incorporados em meu discurso historiográfico. Meu mestre deixava-me embriagar em meus devaneios, tal como o preceptor goetheano em Wilhelm Meister, que professava:

Não é obrigação do educador de homens preservá-los do erro, mas sim orientar o errado; e mais, a sabedoria dos mestres está em deixar que o errado sorva de taças repletas de seu erro. Quem só saboreia parcamente seu erro, nele se mantém por muito tempo, alegra-se dele como de uma felicidade rara; mas quem o esgota por completo, deve reconhecê-lo como erro [...] (GOETHE, 2006, p. 470-471).

\section{A partida}

Essa viagem começou em fevereiro de 2009 quando fiz minha matrícula no curso de mestrado em História Social na Universidade Estadual de Londrina. Parti sem saber o destino da viagem e sem conhecer o trajeto. Apenas tinha em mente que o caminho se faria ao caminhar e, em mãos, o fio de Ariadne, que soltava aos poucos a fim de que mais tarde pudesse voltar e rever o percurso. Iniciei o trajeto da pesquisa levando comigo o romance Nove noites, do jornalista e escritor brasileiro contemporâneo Bernardo Carvalho. Autor de cerca de uma dezena de livros, Carvalho ocupa uma posição de destaque na história da 
literatura brasileira de nosso tempo. Altamente premiado, ${ }^{4} \mathrm{o}$ autor, nesse livro, ficcionalizou a história de Buell Quain, pesquisador em antropologia da Universidade de Columbia, EUA, que veio ao Brasil em 1938 a fim de realizar pesquisas de campo em aldeias indígenas brasileiras e que, no ano seguinte, suicidou-se quando tentava retornar da aldeia Cabeceira Grossa, dos índios craôs, para a cidade de Carolina, no Maranhão. O livro interessou-me mais por conta de sua estrutura narrativa e do tratamento dado às fontes do que propriamente pelo tema historiografado, o recorte temático que a narrativa faz na história cultural brasileira, a saber: a história das expedições científicas nacionais e internacionais que adentraram o país na primeira metade do século XX em busca de fontes de pesquisa para estudos científicos diversos, desde a procura por minérios sedimentados em solo amazônico até a coleta e catalogação de material cultural produzido nas aldeias do país, como "[...] armas, instrumentos musicais, cerâmica e outros objetos que mostrassem a cultura dos habitantes da região" (GRUPIONI, 1998, p. 94).

Nesse trecho da viagem debrucei-me sobre questões referentes à chamada metaficção historiográfica, que, segundo a crítica literária canadense Linda Hutcheon, em seu livro/manifesto Poética do pós-modernismo: história, teoria e ficção, "[...] é uma maneira narrativa de dar sentido ao passado que deliberadamente embaça a fronteira entre literatura e historiografia" (HUTCHEON, 1991, p. 122). ${ }^{5}$ Nove noites seria, portanto, uma metaficção historiográfica, nas palavras do historiador José A. Vasconcelos, "[...] um estilo literário que se constitui de forma híbrida, em parte ficcional e em parte historiográfico, e que aponta para o caráter quimérico de uma distinção entre História e Ficção" (VASCONCELOS, 2005, p. 20). Uma espécie de relato de pesquisa em que o narrador conta as experiências que teve enquanto dedicava-se à investigação biográfica de Buell Quain. Além de reproduzir trechos das fontes históricas pesquisadas, como cartas, entrevistas, imagens, o autor incluiu no texto informações ficcionais e conferiu a elas o mesmo valor dado aos registros historiográficos. $O$ mais interessante é que, se por um lado Bernardo Carvalho procurou imprimir as informações dos documentos historiográficos nas vozes dos personagens ficcionais, por outro, ele ficcionalizou sua autobiografia, levando o leitor a fundir sua identidade com a do narrador.

No início da trama, o narrador conta que tomou conhecimento de Buell Quain por meio de um texto jornalístico escrito pela antropóloga brasileira Mariza Corrêa que então trabalhava na Universidade de Campinas e publicava vários trabalhos sobre pesquisadores estrangeiros no Brasil durante o Estado Novo. O narrador explica como estabeleceu os primeiros contatos com Mariza, como foi conquistando sua confiança e convencendo-a de que ele desejava apenas escrever um romance.

\footnotetext{
${ }^{4}$ Além dos prêmios de literatura da Biblioteca Nacional e do Portugal Telecom que Bernardo Carvalho recebeu em 2003 com o livro Nove noites, o autor foi premiado com Mongólia (2003) e O sol se põe em São Paulo (2007).

${ }^{5}$ Ver discussão sobre esse trecho de Hutcheon (VASCONCELOS, 2005, p. 89).
} 
[...] se de início [a professora] chegou a desconfiar do meu interesse por aquele homem, não perguntou as minhas verdadeiras intenções. ou, pelo menos, não insistiu em saber as minhas razões. Supôs que eu quisesse escrever um romance, que meu interesse fosse literário, e eu não a contrariei [...].

Os papéis estão espalhados em arquivos no Brasil e nos Estados Unidos. Fiz algumas viagens, alguns contatos, e aos poucos fui montando um quebra-cabeça e criando a imagem de quem eu procurava. Muita gente me ajudou. Nada dependeu de mim, mas de uma combinação de acasos e esforços que teve início no dia em que li, para o meu espanto, o artigo da antropóloga no jornal e, ao pronunciar aquele nome em voz alta, ouvi-o pela primeira vez na minha própria voz (CARVALHO, 2006, p. 12).

Pois logo no início do romance a confusão entre autor e narrador é instaurada. É fácil imaginar que foi Bernardo Carvalho quem entrou em contato com a professora Mariza a fim de obter informações a respeito de Quain e escrever um romance. Porém, no momento em que ele imprimiu a referencialidade histórica de seu texto ao falar sobre os meandros de sua pesquisa e de seu contato com a autora do artigo, introduziu a ficcionalidade na história afirmando que, diferentemente de seu interesse, o interesse do narrador não era apenas o de escrever um romance histórico, mas também o de desvendar uma questão biográfica, o mistério de um som, um mesmo som para dois nomes: Buell Quain/Bill Cohen, cuja semelhança sonora ele percebera "[...] ao pronunciar aquele nome em voz alta [...]" .

Por ser recorrente em vários romances do autor a estratégica narrativa de mesclar as identidades de autor e narrador, ela já foi comentada outras vezes por outros críticos literários. O diretor de cinema e crítico literário Daniel Augusto, em artigo intitulado Um quiproquó metódico: os romances de Bernardo Carvalho (AUGUSTO, 2004), apresentou uma crítica à obra de Carvalho, uma crítica que em alguma ocasião poderia ser considerada negativa, mas, em se pensando em alternativas de escrita da história, tornou-se positiva para meu argumento. Pois é justamente o estilo "metódico" de Carvalho que o aproxima do historiador. Daniel Augusto comentou a respeito da repetição 'metódica' nos livros de Carvalho dos personagens escritores, bem como da confusão calculada que ele produz entre essas duas vozes narrativas: o autor e o narrador.

Há muitas situações descritas nos romances de Bernardo Carvalho em que o confronto entre arte e realidade aparece. Encontramos desde um personagem escritor cuja obra oscila sem definir fronteiras entre o diário e o romance, até situações cômicas de personagens que apaixonam-se por um escritor e dão com os burros na água ao perceberem que confundiram autor com narrador. São situações pontuais que ganham ressonância se lembrarmos que - não só em "As iniciais", mas em grande parte de seus romances - muitos dos seus 
narradores são escritores, mesmo que frustrados, em busca de ordenar a própria experiência. Ou seja: vivem numa espécie de situação-limite para pensar a relação - ou a falta de relação - entre arte e realidade (AUGUSTO, 2004).

Às vezes as fontes de Carvalho são literalmente citadas, porém, em determinadas ocasiões, as informações historiograficamente constituídas aparecem na voz de algum personagem ficcional. Pode-se dizer que elas são descontextualizadas, retiradas de sua historicidade. Se isso falseia a 'verdade histórica' , também demonstra que o autor teve acesso a muitas informações 'objetivas' a respeito de Buell Quain, informações que qualquer historiador, disposto a realizar a pesquisa, poderia ter. Mas, tal como o romancista, logo o historiador perceberia que nem todos os momentos da história de Quain, especialmente aqueles que tratam do tempo em que ele esteve entre os índios brasileiros e que é decisivo para o desvendamento da causa de sua morte, foram documentados. Carvalho, por escrever um texto ficcional, pôde tranquilamente lançar mão de sua imaginação histórica e supor o que poderia ter acontecido ao antropólogo. Mantém-se, no entanto, para sempre, o enigma da morte de Quain, mantém-se a impossibilidade de se saber sobre o passado, mantém-se a pergunta sem resposta: o que matou o antropólogo? Eis o limite dos fatos, eis o transbordamento da imaginação.

[...] a narrativa histórica não reproduz os eventos que descreve; ela nos diz a direção em que devemos pensar acerca dos acontecimentos e carrega o nosso pensamento sobre os eventos de valências emocionais diferentes. A narrativa histórica não imagina as coisas que indica: ela traz à mente imagens das coisas que indica, tal como o faz a metáfora (WHITE, 1994b, p. 107-108).

Esse "carregamento do pensamento" , feito pelas inúmeras fontes do passado que encontramos ao longo da vida, é o que alimenta nossa imaginação histórica e nos traz à mente vivas imagens de outras épocas, vivas imagens daquilo que não se viu. Um filme, um quadro, um livro, aos poucos um cenário fabuloso projeta-se no presente. ${ }^{6}$

Retornando ao debate referente à categoria "metaficção historiográfica" , gostaria de apresentar algumas questões colocadas por Hutcheon no livro anteriormente citado. Nesse trabalho, a autora pretendeu estabelecer uma poética para o fenômeno cultural do pós-modernismo que, segundo ela, seria "[...] uma estrutura conceitual flexível

\footnotetext{
6 Para ilustrar esse "trazer à mente" , citarei um pequeno trecho do texto de Orest Ranum na História da vida privada: "Nunca saberemos o que havia nas paredes do quarto dos Boucher, mas não é absurdo imaginar, sobre a lareira do escritório, um busto de Voltaire ou de um chinês - típico da Paris do século XVIII - e, no quarto, um crucifixo preso ao cortinado da cama." (RANUM, 1991, p. 225, grifo nosso).
} 
que poderia, ao mesmo tempo, constituir e conter a cultura pós-moderna e nossos discursos tanto a seu respeito como adjacentes a ela" (HUTCHEON, 1991, p. 11). Nota-se, com essa definição, que o projeto da autora é bastante amplo: ela procura uma categoria que, por ser aberta, dê conta de toda a estilística contemporânea, bem como dos discursos a respeito e adjacentes a ela. Mas, me pergunto, será que as formas pós-modernas de romance histórico, o que Hutcheon chamou de metaficção historiográfica, são mesmo universais hoje em dia?

No capítulo intitulado Metaficção historiográfica: o passatempo do tempo passado, a autora diferenciou a metaficção historiográfica do romance histórico. Nesse trecho, ela afirmou que além da fábula, da estória heróica e do romance histórico, categorias ficcionais propostas por Umberto Eco, há uma quarta maneira de narrar o passado: a metaficção historiográfica (HUTCHEON, 1991, p. 150). Segundo Hutcheon, o autor de uma metaficção, ao intercalar em seu texto ficcional as "convenções paratextuais da historiografia" , chama a atenção do leitor justamente para o fato de que tanto historiadores quanto romancistas, ao produzirem um texto, criam sentidos para o passado. Disse ela:

[...] A metaficção historiográfica chama a atenção para esse fato com a utilização das convenções paratextuais da historiografia (especialmente as notas de rodapé) para inserir e também debilitar a autoridade e a objetividade das fontes e das explicações históricas. [...] a ficção pósmoderna não aspira a contar a verdade tanto quanto aspira a perguntar de quem é a verdade que se conta. Menos do que associar essa verdade a pretensões de legitimização empírica, ela contesta o fundamento de qualquer pretensão de possuir essa legitimização. Como pode o historiador (ou o romancista) verificar qualquer relato histórico por comparação com a realidade empírica do passado, a fim de testar a validade desse relato? Os fatos não são preexistentes, e sim construídos pelos tipos de perguntas que fazemos aos acontecimentos (HUTCHEON, 1991, p. 162, grifo nosso).

Semelhante à critica de Linda Hutcheon à pretensão de quem quer que escreva sobre o passado, seja historiador ou romancista, de comprovar empiricamente a realidade vivida por meio da apresentação de documentos históricos, criando, assim, a noção de "fato histórico" , é a leitura de Hayden White em seu ensaio intitulado O fardo da história:

[...] Muitos historiadores continuam a tratar os seus "fatos" como se fossem "dados" e se recusam a reconhecer, diferentemente da maioria dos cientistas, que os fatos, mais do que descobertos, são elaborados pelos tipos de pergunta que o pesquisador faz acerca dos fenômenos que tem diante de si (WHITE, 1994a, p. 56).

White, no entanto, introduziu um novo elemento em sua crítica: a afirmação de que os historiadores, diferentemente da maioria dos demais cientistas contemporâneos, não 
reconhecem a relatividade de seus dados, ao contrário, cismam em diferenciar seus 'textos' de seus 'contextos', utilizando como fundamento para tal diferenciação as noções de "fonte histórica" e "bibliografia", onde os 'fatos' (textos) seriam dados pelas 'fontes', e os 'dados' (contextos), pela 'bibliografia' . Vasconcelos no livro Quem tem medo de teoria? também faz apontamentos precisos, no tópico $O$ pósmodernismo e a escrita da História, a respeito do que ele chama de "tendências pósmodernistas" e suas relações com a História e os historiadores. Ele diz o seguinte:

[...] O que há de original no pós-modernismo, portanto, não é a suspeita do valor - moral ou epistemológico - do conhecimento histórico, mas uma incorporação crítica da História na crítica à modernidade. Em sua cruzada contra a afirmação de verdades universais e atemporais herança do Iluminismo - o pós-modernismo invoca a História para denunciar o caráter contingente de qualquer valor, de qualquer verdade, e para nos lembrar, uma vez mais, que toda representação é historicamente construída.

[...] O que, na verdade, assusta os historiadores são duas outras tendências pós-modernistas: a insistência em submergir a História no âmbito da Literatura, e o esmaecimento da distinção entre texto e contexto (VASCONCELOS, 2005, p. 89-91).

Após trabalhar alguns meses com essas questões referentes à estilística de Nove noites e à categoria de metaficção historiográfica, encontrei-me em dificuldade de, por meio do discurso analítico, dar conta da poética de um texto literário. Resolvi, então, envolver-me mais profundamente com os textos analíticos, exatamente aqueles que costumam nomear os romances contemporâneos como metaficções historiográficas. Dediquei-me sobre alguns textos acadêmicos, sobre a crítica literária acadêmica que se dedica à 'decodificação' da literatura.

\section{A primeira curva no percurso}

Da janela do trem eu entrevia o momento presente.

Eis que chegamos ao $2^{\circ}$ milênio da era cristã. Vivemos a era da informática, ${ }^{7}$ da alta tecnologia, da claustrofobia terrestre, da colonização do espaço. O mundo ficou pequeno para os bilhões de seres humanos que continuamente devastam o espaço onde

\footnotetext{
7 Termo criado no ano de 1962.
} 
vivem. Afora algum bug $^{8}$ no caminho, o ano de 2000 começou tranquilo, mesmo que a passagem de um século para outro estimule a criação de misticismos, previsões, profecias escatológicas, o que é ainda mais forte quando tal passagem coincide com uma virada de milênio, como foi o caso. Ao longo de todo o século $X X$, artistas, escritores, diretores de filmes, religiosos, intelectuais criaram suas previsões para o ano 2000, imaginaram como seria a sociedade humana no período, quais as dificuldades que ela encontraria para garantir sua sobrevivência e como lidaria com elas. Agora, enfim, chegamos ao futuro. Vivemos o lendário século XXI. A questão, entretanto, que novamente se faz é a seguinte: Quem somos nós? Que sociedade é essa, globalizada, envolta em contradições, marcada pela fragmentação e pela individualização?

A organização social humana contemporânea apresenta características que, se avaliadas em conjunto, a singularizam. Mas, o que nos faz únicos? O que nos diferencia de todas as outras sociedades humanas? Alguns, muito crentes de que são o topo da evolução humana, diriam: temos tecnologia, temos alta tecnologia, logo, somos os mais evoluídos. Contudo, já na década de 1970, o filósofo e antropólogo francês Pierre Clastres quebrou com a lógica dessa afirmação no artigo intitulado $A$ sociedade contra o Estado, em que ele disse:

[...] Se entendermos por técnica o conjunto dos processos de que se munem os homens, não para assegurarem o domínio absoluto da natureza (isso só vale para o nosso mundo e seu insano projeto cartesiano cujas consequências ecológicas mal começamos a medir), mas para garantir um domínio do meio natural adaptado e relativo às suas necessidades, então não mais podemos falar em inferioridade técnica das sociedades primitivas: elas demonstram uma capacidade de satisfazer suas necessidades pelo menos igual àquela de que se orgulha a sociedade industrial e técnica (CLASTRES, 2003, p. 209, grifo nosso).

"[...] de nada serve opor o fuzil ao arco" , diz o filósofo, pois a conclusão a que se chegará é ilusória (CLASTRES, 2003, p. 210). Alguém muito perspicaz poderia ainda dizer: 'O fuzil é mais potente, logo, serve mais às necessidades humanas'. Mas, o que é a necessidade humana senão um dado cultural? O fuzil serve mais àquela sociedade que opera em termos de genocídio, que tem 'necessidade' de assassinar um grande número de pessoas. Desse ponto de vista, não é a técnica o que nos singulariza, mas o uso que fazemos dela.

8 "Bug do milênio" foi a denominação dada a uma possível falha computacional que atingiria os programas de computadores na virada do ano 2000 e causaria, por exemplo, graves problemas nos sistemas bancários do mundo todo. Para maiores informações sobre o fenômeno, acesse a seguinte reportagem, publicada pela revista Isto É. (MUITO estrago... , 1999). 
Imerso num ambiente fartamente documentado, o historiador do século XXI tem suas ações intermediadas pelo suporte digital, seja no momento de digitar um texto, fazer uma pesquisa na internet, enviar documentos acadêmicos, corresponder-se com seus pares. As possibilidades são muitas. Observando panoramicamente, arrisco-me, com cautela para não causar muito alvoroço, a dizer que a tecnologia atua sobre o fazer do historiador contemporâneo em grau bem mais elevado do que em um passado bastante recente. Sítios virtuais de ministérios públicos, universidades, museus, bibliotecas, arquivos públicos e privados, revistas científicas, grupos de pesquisa, jornais estão disponíveis na internet, possibilitando o contato rápido do pesquisador com os responsáveis pelos acervos ou, como acontece em alguns casos, permitindo o acesso direto do pesquisador às suas fontes de pesquisa. Textos científicos, documentos jurídicos, acervos imagéticos e bibliográficos podem ser acessados, com ou sem restrições, na rede.

O historiador do século XIX não supunha essa digitalização do homem. Era imprescindível para ele o deslocamento para bibliotecas e arquivos públicos ou privados, para sítios arqueológicos ou antropológicos distantes em busca das fontes de pesquisa. Isso não significa que a pesquisa de campo atualmente seja desnecessária ou substituível, contudo, tornou-se possíve/ realizar trabalhos acadêmicos sem que a locomoção física do pesquisador até sua fonte seja imprescindível.

Uma das consequências de tal disponibilidade documental, somada ao aumento do número de profissionais no mercado intelectual, foi a multiplicação de trabalhos científicos em todas as áreas do conhecimento. No caso da historiografia e de áreas vinculadas à criação de sentido para o passado, não foi diferente. No artigo intitulado Historiografia e pós-modernismo, o historiador holandês Frank Ankersmit comentou a respeito do fenômeno de produtividade historiográfica:

A questão crucial agora é que atitude tomar quanto a essa superprodução de literatura histórica que está se espalhando qual um câncer por todas as suas áreas. $O$ desejo reacionário pelo comportado ambiente da história de cinquenta anos atrás é tão sem sentido quanto uma resignação desalentada. Temos de compreender que não há retorno. Já foi calculado que hoje em dia há mais historiadores debruçados sobre o passado do que a quantidade total de historiadores desde Heródoto até 1960 (ANKERSMIT, 2001, p. 115).

Nesse mar de sinais digitais, a pergunta que se impõe primeiramente ao historiador do século XXI é a seguinte: uma sociedade permeada pela 'infinitude' da memória digital, como distinguir entre o que deve ser lembrado e o que deve ser esquecido? Que artigo vale a pena ser lido, qual texto deve ser apagado?

Percebendo que essa janela era ampla por demais, resolvi fechá-la até o ponto em que pudesse observar o campo apenas por uma pequena fresta. Enfim, resolvi pesquisar 
a recepção do discurso historiográfico contemporâneo nas teses dos alunos de diferentes modalidades dos cursos de doutorado em Letras. Procurei perceber como as teses narram a história romanceada, de que maneira apropriam-se do discurso historiográfico para legitimar sua argumentação, se utilizam, e como, os conceitos de pós-modernidade e metaficção historiográfica e, por fim, a qual escola de pensamento historiográfico sua argumentação estaria filiada. Procurava conhecer a maneira como a historiografia dita "pós-moderna" é acessada pelos críticos literários acadêmicos, como ela se dá na prática discursiva acadêmica contemporânea.

Escolhi, entre as teses selecionadas, uma para começar minha leitura. Intitulada $A$ metaficção historiográfica no romance "Os cus de Judas", de António Lobo Antunes, a tese foi escolhida justamente em função do nome (metaficção historiográfica), mas acabei focalizando os trabalhos que tratavam acerca de António Lobo Antunes. O escritor foi assunto de dezoito teses de Letras financiadas pelas Capes e datadas de 1999 a 2008. Dessas dezoito, oito foram disponibilizadas na internet; dessas oito, duas li por completo.

Fazendo uma análise panorâmica sobre esses oito trabalhos e outras tantas 'produções científicas' que li sobre a categoria de romance em questão e/ou sobre Lobo Antunes, bem como sobre as discussões contemporâneas a respeito da teoria da história, percebi algumas peculiaridades na maneira como esses diferentes campos do conhecimento se relacionam com a arte literária. Chamou-me a atenção a tendência do crítico literário em reivindicar para o romance histórico (ou metaficção historiográfica) um lugar de verdade, ou seja, uma autoridade para construir uma versão verdadeira a respeito do passado, a vontade de dar voz aos excluídos da historiografia, ou mesmo fazer justiça às memórias esquecidas pelos historiadores. ${ }^{9}$ Acredito, particularmente, que o romance histórico possa dar conta de muita singularidade humana, mas acho curioso que esse impulso justiceiro e revolucionário parta do crítico literário. Afinal, justamente o que ele critica na historiografia é o que tão enfaticamente reivindica para a literatura: o poder de criar uma versão verdadeira e redentora para o passado. Por outro lado, tem-se contemporaneamente um movimento contrário no campo historiográfico. Há historiadores que reconhecem a fragilidade epistemológica da historiografia e admitem a impossibilidade da linguagem dar conta da experiência vivida. Talvez os desastres bélicos do século $X X$, o medo atômico e a ameaça da extinção humana tenham provocado um descrédito na objetividade do discurso historiográfico fazendo com que esses historiadores promovessem uma reorganização geral em torno do passado, revissem seus conceitos básicos, bem como a maneira de interpretá-

\footnotetext{
9 Diz uma das autoras das teses pesquisadas que a partir do advento artístico da literatura "as diferenças não podem ser mais reprimidas pela cultura oficial" diz ainda que a literatura possibilita "o registro das culturas até então rejeitadas justamente por não terem valor ou interesse para a cultura oficial" ; encoraja o leitor a desprezar a historiografia, pois "não é de interesse na sociedade portuguesa que a história da derrota na guerra de Angola seja de conhecimento público" ; proclama que "estamos diante de um romance pós-moderno cuja narrativa enfatiza a problematização dos acontecimentos históricos através da ficção e que permite que os 'ex-cêntricos' tenham voz, a mesma voz que Ihes seria negada pela história oficial" . (SILVA, 2007).
} 
los. Essa mudança de mentalidades foi apontada por Marc Bloch em sua Apologia da história ou o ofício do historiador, escrita entre os anos de 1942 e 1944:

Ora, nossa atmosfera mental não é mais a mesma. A teoria cinética dos gases, a mecânica einsteiniana, a teoria dos quanta alteraram profundamente a noção que ainda ontem qualquer um formava sobre a ciência. Não a diminuíram. Mas a flexibilizaram. Com certeza, substituíram, em muitos pontos, o infinitamente provável, o rigorosamente mensurável pela noção da eterna relatividade da medida (BLOCH, 2001, p. 49).

Seria exatamente nessa interconexão dos caminhos da crítica, em busca do direito à verdade, com os da historiografia, receosa de seu estatuto de verdade, que a categoria de metaficção historiográfica, tal como nomeada por Linda Hutcheon, se estabeleceria. Tanto para o crítico quanto para o historiador que está em busca de alternativas estilísticas para suas narrativas, esse estilo narrativo apresentaria uma possibilidade de, mantendo a referencialidade histórica, criar um texto mais artístico.

Mas, eis que a literatura de Lobo Antunes pareceu-me bem mais interessante que as explicações historiográficas e/ou estilísticas dos críticos de seus romances, pois, no geral, as teses 'matam' seus objetos ao tentar defini-los. Ali onde se fala da arte, a arte não está. $O$ crítico acadêmico contemporâneo fala de expressões artísticas do homem, no entanto, seus textos são discursos que, mesmo não sendo, tendem ao científico. ${ }^{10} \mathrm{E}$ por quê? Bem, mestrando ou doutorando, o crítico produz dissertação e tese, artigos para revistas especializadas, participa de congressos acadêmicos e escreve relatórios de pesquisa. 0 paradigma da 'quantidade produtiva' que assola o ambiente acadêmico, um paradigma industrial, traz também o crítico acadêmico para bem mais próximo, em sua prática, da historiografia dos fatos do que da ficção.

\section{Novamente um desvio}

Conforme analisava as teses selecionadas, envolvia-me cada vez mais com as narrativas antunianas. Percebi que essa era mais uma curva no caminho de minha pesquisa,

${ }^{10}$ Crítico literário acadêmico é todo aquele que analisa textos literários, sejam estudiosos alocados em cursos de Letras, História, Antropologia, Psicologia, Ciências Sociais etc. O foco desse trabalho acabou recaindo sobre trabalhos defendidos por pós-graduandos em Letras porque as teses lidas foram todas produzidas a partir desse campo do conhecimento. 
novamente eu estava às voltas com a literatura ficcional. Memória de elefante e Os cus de Judas, textos autobiográficos escritos no final da década de 1970, momento em que o autor enfrentava turbulências existenciais profundas, esses romances são uma espécie de autoanálise. O personagem, tal como o autor, volta da guerra em Angola, separa-se de mulher e filhas e tenta reconfigurar-se no cenário cotidiano de Lisboa. A marca da guerra em sua memória o atormenta a ponto de lhe ser necessário escrever.

Desde o retorno ao seu país, em 1973, até o ano de 1985, Lobo Antunes trabalhou como psiquiatra no tradicional hospital Miguel Bombarda, antigo Rilhafoles, fundado em 1848. Nesse período, produziu ensaios e artigos científicos que foram publicados em revistas acadêmicas especializadas (BILANGE, 2007, p. 12-3). Escritos em parceria com Maria Inês Dias (Loucura e criação artística: Ângelo de Lima, poeta de Orpheu, 1974) e Daniel Sampaio (Lewis Carroll: a esquizofrenia esconjurada, de 1978; O psicótico na família e na instituição: a propósito de dois casos clínicos, 1979; D. Duarte ou a depressão no trono, de 1980; Violência e relação terapêutica: os Hitlers de bolso no poder, 1981), esses trabalhos giram em torno de questões referentes ao desajuste indivíduo-sociedade: loucura e criação artística, loucura e instituição psiquiátrica, loucura e poder, violência e poder psiquiátrico. Foi também nessa época que Lobo Antunes escreveu sua primeira trilogia ficcional, abrangendo os livros Memória de elefante, Os cus de Judas e Conhecimento do inferno, onde abordou a temática da guerra, das relações entre homens e mulheres, do universo contraditório dos hospitais psiquiátricos em Portugal, considerado como um microcosmo representativo do país inteiro, especialmente de si mesmo. É como se todos os personagens, incluindo o próprio autor, figurassem pessoas em análise.

Escrito em 1976, Memória de elefante é narrado em terceira pessoa e tem como protagonista um psiquiatra, alter ego do autor. A narrativa abrange a temporalidade de um dia, do amanhecer ao amanhecer, e é focada na percepção do personagem sobre a situação atual de sua vida. Uma viagem pela mente, pelo pensamento em conflito de um jovem médico, ex-combatente em Angola, insatisfeito com seu papel familiar e social, desiludido com sua profissão, ultrajado pela pátria, submerso na solidão... e tentando intensamente reinventar-se e fazer fluir suas vontades.

De ressaca, após uma noite mal dormida, o médico chega ao hospital e começa o atendimento na sala de consultas. Logo nota a presença de uma nova paciente "[...] ziguezagueando de injecções, de camisa a flutuar em torno do corpo como o espectro de Charlotte Brontë vagando no escuro de uma casa antiga" (ANTUNES, 2009, p. 14). De acordo com o laudo do médico que a internou, seu diagnóstico é o de "esquizofrenia paranóide e tentativa de suicídio" (ANTUNES, 2009, p. 14-5). A mulher anda e fala pelos corredores do hospital e enche a sala com seu vocabulário chulo. O médico e a enfermeira 
observam. Ele rascunha mais algumas palavras libidinosas no bloco de papel e entrega-o à enfermeira, indicando que o problema da paciente é sexual. Avisa-Ihe, porém, que a lição não Ihe foi ensinada por Freud, mas pela sua própria experiência de vida: "[...] Aprendi isto com a minha primeira mestra de lavores, diga-se à puridade e de passagem que o melhor clitóris de Lisboa" (ANTUNES, 2009, p. 16). A enfermeira, contrariada, sai da sala. Diz que irá auxiliar outros médicos. Enquanto isso, a paciente, que continua falando suas frases sexuais desconexas, acaba por levar o psiquiatra às lembranças de sua infância e adolescência, aos momentos em que iniciou seu conhecimento dos prazeres e infortúnios que as mulheres lhe poderiam provocar.

Quando é que eu me fodi?, perguntou-se o psiquiatra enquanto a Charlotte Brontë prosseguia impassível o seu discurso sobre Lewis Carroll grandioso. Como quem enfia sem pensar a mão no bolso à procura da gorjeta de uma resposta mergulhou o braço na gaveta da infância [...] (ANTUNES, 2009, p. 21).

Passando da infância à adolescência, o psiquiatra chega ao ponto crítico da teoria freudiana: a sexualidade. Observando pela janela o pátio e vendo um paciente em pleno gozo masturbatório, ouvindo a Charlotte Brontë repetir suas "conas da mãe" ${ }^{11} \mathrm{e}$ seus "cabrões" , o médico relembra, de "lupa psicanalítica em punho" , sua primeira trepada em um prostíbulo lisboeta:

[...] preparava-se para explorar de lupa psicanalítica em punho as angustiosas vicissitudes de sua estreia sexual entre uma garrafa de permanganato e uma colcha duvidosa que conservava viva, junto da almofada, a pegada de yeti da sola do cliente anterior, demasiado apressado para se preocupar com o detalhe insignificante dos sapatos ou suficientemente púdico para manter as peúgas naquele altar de blenorragias a taxímetro, quando a Charlotte Brontë o despertou para a realidade presente na manhã hospitalar [...] (ANTUNES, 2009, p. 23, grifo nosso). ${ }^{12}$

Depois de passar a manhã toda no hospital, almoçar com um amigo num conhecido restaurante, enfrentar a torturante cadeira do dentista após um período de congestionamento no trânsito de Lisboa, assistir, sem coragem para se aproximar, a saída da escola das filhas, o psiquiatra vai ao bar esperar a hora da sessão de terapia em grupo. Ao longo de todo esse percurso, lê-se as memórias em análise do psiquiatra. A infância tolhida,

\footnotetext{
${ }^{11}$ Cona: do latim cunnus. Vulva; vagina.

12 Algumas palavras desse trecho não são conhecidas e/ou utilizadas no português brasileiro, por essa razão, 'traduzi-las-ei' . De acordo com o dicionário consultado Priberam (2012) Yeti: (palavra inglesa, do xerpa yeh-teh). Criatura lendária dos Himalaias, peluda e de formas humanas; o abominável homem das neves; peúga: (latim vulgar peduca, -ae, de pes, pedis, pé). Meia curta; coturno; blenorragia: gonorreia.
} 
as implicâncias da mãe com seu jeito distraído, a lembrança do primeiro encontro com a exmulher, os dias de guerra em Angola... Por todo o percurso mental por que passa o médico, acompanham elementos da clínica psicanalítica, palavras-conceitos, técnicas de observação. Nas páginas seguintes, contudo, momento em que o psiquiatra se aproxima da sessão de terapia, a crítica à prática freudiana ganha contornos bem mais nítidos. Novamente o descompasso do médico com sua prática psicológica acontece em uma situação de autoanálise. No tempo presente de sua história, o personagem sente-se normatizado, anestesiado, castrado pela lógica analítica de resolução dos problemas da vida.

[...] Que porra de lavagem à cornadura é esta que saio daqui torcido como um velho com reumático, lumbago, ciática, bicos de papagaio e dor de dentes, alma de rafeiro a ganir a caminho de casa, e no entanto volto, volto pontualmente dia sim dia não para receber mais trolha ou uma indiferença total e nenhuma resposta às minhas angústias concretas, nenhuma ideia acerca de como sair deste poço ou pelo menos visionar um nada de ar livre lá em cima, nenhum gesto que me mostre a direcção de uma certa tranquilidade, de uma certa paz, de uma certa harmonia comigo: Freud da puta judia que te pariu vai levar no cu do teu Édipo. Abriu a porta do grupo e em vez de declarar Merda para todos disse Boa tarde e foi sentar-se, disciplinadamente, na única cadeira livre da sala (ANTUNES, 2009, p. 113). ${ }^{13}$

Conforme o médico se coloca na pele do 'doente' é que ele vai percebendo uma possibilidade: a de as técnicas médicas de cura não serem suficientes para sanar, ou mesmo aliviar, o sofrimento. Ressalta, em sua crítica, o descontentamento com a manutenção da passividade de seu próprio corpo que, mesmo indo dia sim dia não ocupar uma cadeira na sala do terapeuta, sai de lá sempre como um velho com reumático e sem respostas concretas à suas angústias. Ele demora a perceber que as soluções para seus problemas não poderiam simplesmente ser receitadas pelo terapeuta qual um remédio milagroso, que a saída do poço sem fundo e sem ar não estava localizada na sala de análise, mas em seu próprio labirinto psíquico.

Essa insatisfação do psiquiatra com a terapia reflete-se em sua prática profissional e é expressa em vários momentos da narrativa. O psiquiatra passa a duvidar da saúde de médicos e enfermeiras, indagando-se sobre os motivos que levam essas pessoas a escolherem o Hospital Psiquiátrico como ambiente de trabalho. "[...] Quem entre aqui para dar pastilhas, tomar pastilhas ou visitar nazarenamente as vítimas das pastilhas é doente, sentenciou o psiquiatra no interior de si mesmo" (ANTUNES, 2009, p. 15). Em meio à profunda crise existencial, cercado por todos os lados pela loucura e a depressão, o

\footnotetext{
13 Lumbago: dor na região lombar; rafeiro: Diz-se de certa casta de cães para guardar o gado; no sentido figurado, é um indivíduo que acompanha sempre outro, como o cão acompanha o dono; bajulador. (PRIBERAM, 2012).
} 
psiquiatra percebe que os diagnósticos médicos são arbitrários, que a psiquiatria é arbitrária. Questiona-se sobre a ética desse papel que ele desempenha: o de

[...] colaborar não colaborando com a [...] pavorosa máquina doente da Saúde Mental trituradora no ovo dos germenzinhos de liberdade que em nós nascem sob a forma canhestra de um protesto inquieto, pactuando mediante o meu silêncio, o ordenado que recebo, a carreira que me oferecem: como resistir de dentro, quase sem ajuda à inércia eficaz e mole da psiquiatria institucional, inventora da grande linha branca de separar a "normalidade" da "loucura" através de uma complexa e postiça rede de sintomas, da psiquiatria como grosseira alienação, como vingança dos castrados contra o pénis que não têm, como arma real da burguesia a que por nascença pertenço e que se torna tão difícil renegar [...] (ANTUNES, 2009, p. 39).

Esse movimento crítico de Lobo Antunes em relação à psiquiatria, enquanto prática profissional, e à psicanálise, enquanto terapêutica pessoal de cura, é que o aproxima da literatura. Percebendo a intransigência da psiquiatria-institucional em tratar a loucura e a impossibilidade das técnicas psicanalíticas, por si mesmas, em solucionar os distúrbios psíquicos, Lobo Antunes recorreu à escrita de si.

O amigo roçou a barba loira no ombro do médico: [...]

- Tens escrito, interrogou.

De mês a mês desfechava de súbito esta pergunta aterradora, porque para o psiquiatra o manuseio das palavras constituía uma espécie de vergonha secreta, obsessão eternamente adiada.

- Enquanto o não fizer posso sempre acreditar que se o fizer o faço bem [...]. Mas se começar um livro a sério e parir merda que desculpa me fica? (ANTUNES, 2009, p. 57).

Ainda que a linguagem não dê conta da multiplicidade de formas de existir que a existência é capaz de conter, ainda que ao trazer à consciência o inconsciente ela ateste sua impossibilidade, ela exerce um poder de transformação do mundo, é como o vetor paracélsico em busca do ponto de equilíbrio entre o micro e o macrocosmo.

Ainda que a equação psicanalítica seja produtora de um resultado ilusório por associar coisas diferentes, ela, assim como a literatura, opera no campo da linguagem. Pode, portanto, ser terapêutica, pode transformar estados de espírito, pode transmutar sentimentos. Contudo, a cura não é intrínseca à equação psicanalítica, não há garantias nem prazos para o desaparecimento dos sintomas neuróticos. 
Eis a linguagem transformando o mundo de uma pessoa, ainda que nada no mundo "real" tenha sido mudado. A cura de sintomas neuróticos, ou pelo menos o alívio deles, reside, portanto, na imaginação, esta, por sua vez, se apresenta ao mundo por meio da linguagem.

A transição foi tensa. De psiquiatra a escritor de romances, Lobo Antunes foi do esvaziamento da linguagem analítica à criação da linguagem literária. De início, ele apostou na escrita como uma prática que lhe possibilitaria a significação das inquietações humanas, ainda que provisoriamente. Em Memória de elefante escreveu para fazer fluir seus múltiplos eus, seus sentimentos ambíguos, suas pulsões. Embora as palavras não conseguissem, como em um passe de mágica, fazer desaparecer o poço, a falta de ar ou as angústias. Conforme escrevia, a sensação de incompletude se mantinha. Lobo Antunes deu-se conta de que a palavra não podia falar daquilo que ele sentia, o impulso, o instinto. Por isso, resolveu "[...] travestir as coisas com palavras" .14 Sua frustração por não conseguir satisfazer seus impulsos por meio da linguagem transformou-se em disposição para brincar com o sentido que as palavras poderiam dar às suas vivências. Ele se pôs a jogar com as variantes da vida e, para isso, encarou o livro como uma possibilidade de partilhar de si consigo e com o leitor. Percebeu que as palavras vestem os sentimentos, cobrem-nos com máscaras, dão-lhes aparência. As palavras criam sentidos para os sentimentos, transmutam sensações e permitem, ao escritor, experimentar perspectivas diversas ao perder-se entre seus personagens. Habilidoso com as palavras, Lobo Antunes criou para si um mundo novo, feito de linguagem, onde the foi possível ler e interpretar o mundo. $O$ escritor não se entregou ao encanto objetivo das palavras, mas também não as evitou. Ele usou a palavra, percebeu sua ficção e, por isso, se esbaldou. Criou uma imagem artística, provisória e ao mesmo tempo duradoura, porque compartilhada, de seu inconsciente consciente.

$*$

\section{O encontro com o acaso e a emergência de um novo caminho}

Mas eis que mais uma mudança se aproximava. Essa, no entanto, não foi fruto de uma curva no caminho, foi obra do acaso. Não havia sinais indicando a aproximação da encruzilhada, mas, de repente, eu estava lá, de cara com uma bifurcação. Era o dia vinte e dois de maio de 2010. Eu caminhava pelos corredores da Biblioteca Central da UEL quando topei com uma estante intitulada 'Literatura Alemã' . Os livros que ali estavam chamaram minha atenção porque naquela altura eu estava envolvida com a leitura de Goethe, Novalis e Nietzsche. Corri os olhos pelas lombadas dos livros e encontrei, para minha surpresa, um

14 Referência à entrevista de Lobo Antunes concedida ao programa Entrelinhas, da TV Cultura, durante sua participação no Festival Literário de Parati (Flip), em 2009. Entrevistador: Manuel da Costa Pinto. Disponível em: http://www.youtube.com/watch?v=S5RH9wNyOFE. 
texto do filósofo Peter Sloterdijk. Conhecia o autor de nome, pois ele havia sido citado nas aulas de filosofia, mas não imaginava que escrevia romances. Peguei o livro: $A$ árvore mágica. O título não me esclareceu quanto ao assunto. Abri-o. Na página de rosto, o longo subtítulo: O surgimento da psicanálise no ano de 1785. Tentativa épica com relação à filosofia da psicologia (SLOTERDIJK, 1988). Fiquei intrigada com o subtítulo. Claro e explicativo, típico de textos acadêmicos, dava indícios da visão do autor a respeito da história da psicanálise. Decidi levá-lo. Eu realmente não sabia que essa não seria apenas uma curva no percurso, dessa vez, todo um novo caminho se abria em minha viagem.

Sloterdijk deu um passo de volta na história da psicanálise e trouxe à tona um diálogo filosófico a respeito da cura dos males da alma travado cerca de cem anos antes da viagem de Sigmund Freud à França (1885). A fim de abarcar a mentalidade intelectual europeia que gestou a psicanálise, guiado pelas sugestões de outros filósofos, incluindo aí o próprio Freud, Sloterdijk foi buscar nas referências literárias e filosóficas correntes nos círculos acadêmicos europeus no século XVIII, o surgimento da psicanálise. Em termos narrativos, sua estratégia foi bastante interessante: condensou e corporificou os 'imagináveis encontros bibliográficos' de Freud em Jan Van Leyden, o protagonista do romance, que, por conta disso, transita na trama da história no século XVIII, encontrando-se com importantes figurações filosóficas da época, como Condorcet, Jean-Paul Marat e Ferdinando Galliani. A maior parte da narrativa passa-se na França, embora o protagonista tenha iniciado e terminado seu percurso na Áustria, sua terra natal. Van Leyden é inserido no cenário da corte, encontra-se com membros da maçonaria, perambula pelas ruas de Paris, enfim, percorre espaços antes percorridos por Franz Anton Mesmer, encontra-se com um de seus mais ilustres discípulos, o marquês Armand de Puységur, o primeiro médico, ainda que amador, afirmam os historiadores, a observar os efeitos da hipnose, chamada por ele de sonambulismo magnético, em um de seus pacientes. Como o tempo das ideias ultrapassa o tempo da existência humana e, sendo Van Leyden a figuração de uma ideia, é 'natural' que sua existência ultrapasse o tempo de uma vida. Por isso, ele pode andar pelas ruas de Paris logo após a partida de Mesmer da cidade e transformar-se, ao final da narrativa, no próprio dr. Freud. ${ }^{15}$

Além desses elementos, Sloterdijk misturou aspectos biográficos de Freud com episódios vividos pelo protagonista. Silberstein, por exemplo, que na trama aparece como o

\footnotetext{
${ }^{15}$ Apesar de ser uma abstração com nome de gente, Jan van Leyden teve pelo menos dois homônimos na história. O primeiro, holandês, viveu no século XVI e foi líder religioso anabatista que teve sua prisão decretada pelos juízes da Inquisição. Foi julgado, torturado e queimado devido à acusação de incitar, entre os seus seguidores, a poligamia (ARMS, 2001). O segundo homônimo viveu no século XVIII e, por incrível que pareça, não se chamava Jan van Leyden. É que, nesse caso, o nome recaiu sobre a invenção... a garrafa de Leyden, o primeiro aparato construído em laboratório que era capaz de captar e armazenar a eletricidade. Seu inventor, Pieter van Musschenbroek, realizou suas pesquisas na Universidade de Leyden, na Holanda, por isso, o nome.
} 
amigo de Van Leyden cuja carta teria inspirado o narrador a escrever a história, é homônimo de um expressivo amigo da juventude de Freud, Eduard Silberstein. Depois que a família Freud mudou-se para Viena, as cartas entre os dois amigos se tornaram intensas. Eles conversavam principalmente em espanhol e tratavam de assuntos corriqueiros: de namoradas a viagens pelos campos germânicos, das dificuldades materiais aos livros de literatura. Filosofia também era um dos temas tratados, especialmente depois que Sigmund iniciou o curso de medicina e, logo no primeiro ano, resolveu dedicar-se ao estudo da filosofia e de questões referentes à história da humanidade. Em carta de 17 de julho de 1873, Freud declarou:

Com relação ao próximo e primeiro ano de estudos universitários, posso te dar a informação de que vou utilizá-lo, do princípio ao fim, puramente para os estudos humanísticos, que nada têm com a minha especialidade, mas que, para mim, não deverão ser infrutuosos. [...] Com vistas aos assinalados fins, frequentarei no primeiro ano a faculdade de filosofia. Assim, se alguém me perguntar / ou fizer a ti uma pergunta dirigida a mim / sobre o que quero ser, abstém de qualquer resposta determinada e replica, por exemplo: um sábio, um catedrático ou algo assim (FREUD apud BOEHLICH, 1995, p. 40).

Outro exemplo da correspondência biográfica entre o protagonista da Árvore mágica e Freud é que ambos participaram, acompanhados por Silberstein, de uma sessão magnética. No romance, o assunto é trazido à tona justamente na carta do amigo, que comenta com Jan Van Leyden a respeito da ocasião, em maio de 1785, em que eles foram assistir a apresentação do magnetizador italiano Balsamo Scaferlatti, "discípulo de Swedenborg" , que se encontrava em Viena para mais uma de suas sessões magnéticas. ${ }^{16} \mathrm{~A}$ séance reuniu a nobre sociedade vienense e alguns ilustres burgueses em casa do falecido barão Von Rosenkotz. Cético, Silberstein relembra, Jan posicionava-se a margem do grupo e, como mero espectador, procurava observar o comportamento das damas da sociedade e analisar o semblante dos senhores presentes enquanto aguardava a entrada triunfal de Scaferlatti. De súbito, o conde surgiu no meio do salão. Jan sentiu uma energia diferente, o calor tomou conta do ambiente, os homens começaram a transpirar, as mulheres tornaramse ofegantes e trêmulas, algumas deixaram escapar gritos dissonantes, outras desmaiaram. Mas Scaferlatti levantou o dedo indicador direito acima de sua cabeça e, com esse gesto, captou todos os olhares presentes (SLOTERDIJK, 1988, p. 27-9). Fez-se silêncio, todos estavam magnetizados...

Em Um estudo autobiográfico, Freud relatou que na sua época de estudante assistiu, em Viena, a uma exibição pública apresentada pelo mesmeriano dinamarquês Carl

\footnotetext{
16 É interessante notar a relação entre o nome do magnetizador que figura no romance, Balsamo Scaferlatti, e o do famoso conde siciliano Alessandro di Cagliostro, que era conhecido, naquela época, na esfera ocultista, como Giuseppe Balsamo, e que foi para Viena se apresentar nos círculos da nobreza. (ZWEIG, [1930], p. 59).
} 
Hansen. Naquela ocasião, afirmou, convenceu-se da eficácia da hipnose para a cura das doenças nervosas. Disse ele:

[...] Notara que um dos pacientes em quem se fizera a experiência se tornara mortalmente pálido no início da rigidez cataléptica, e assim havia permanecido enquanto aquela condição havia durado. Isso me convenceu firmemente da autenticidade dos fenômenos da hipnose (FREUD; SALOMÃO, 1924). ${ }^{17}$

Na trama dA árvore mágica, portanto, Jan van Leyden é uma testemunha ocular dos fatos, ou seja, peça fundamental na historiografia. Ele estava lá quando as coisas aconteceram. Ele vivenciou episódios que posteriormente seriam vividos, conhecidos, lidos, aceitos ou negados por Sigmund Freud e toda uma geração de filósofos e historiadores.

Já o artigo de Luc Herman publicado pela revista History and post-war writing em 1990 traz uma análise interessante do livro (HERMAN, 1990, p. 107-124). O autor enfatiza a ideia de que o texto de Henri Ellenberger em The Discovery of the Unconscious fundamenta historiograficamente o romance de Sloterdijk. Segundo ele, tanto os parágrafos sobre o século XVIII da Crítica da razão cínica quanto a história narrada nA árvore mágica são "indubitavelmente" influenciados pela narrativa de Ellenberger. $E_{\text {, tal como }}$ Ellenberger, Sloterdijk relaciona o pensamento de Mesmer ao espírito filosófico iluminista. Eis o que diz Herman mais adiante: "O link entre Van Leyden e Freud é uma consequência

\footnotetext{
${ }_{17}$ Esse texto, por ser uma espécie de testamento intelectual de Freud, é rico em informações a respeito de sua formação profissional. Nesse trecho em que fala de Hansen, dr. Freud está a relembrar das técnicas de cura que dispunha no início de sua longa carreira psicanalítica: Meu arsenal terapêutico continha apenas duas armas, a eletroterapia e o hipnotismo [...]. Meu conhecimento de eletroterapia provinha do manual de W. Erb [1882], o qual proporcionava instruções detalhadas para o tratamento de todos os sintomas de doenças nervosas. Infelizmente, logo fui impelido a ver que seguir essas instruções não era absolutamente de qualquer valia e que o que eu tomara por um compêndio de observações exatas era meramente a construção de fantasia. Foi penosa a compreensão de que a obra do maior nome da neuropatologia alemã não tinha maior relação com a realidade do que um livro de sonhos 'egípcio' vendido em livrarias baratas, mas ajudou-me a livrar-me de outro fragmento de inocente fé na autoridade, da qual eu ainda não estava livre. Assim, pus de lado meu aparelho elétrico, mesmo antes de Moebius haver salvo a situação, explicando que os êxitos do tratamento elétrico em distúrbios nervosos (até onde havia algum) eram o efeito de sugestão por parte do médico. Com o hipnotismo o caso foi melhor. Enquanto ainda estudante, assistira a uma exibição pública apresentada por Hansen o 'magnetista' e notara que um dos pacientes em quem se fizera a experiência se tornara mortalmente pálido no início da rigidez cataléptica, e assim havia permanecido enquanto aquela condição havia durado. Isso me convenceu firmemente da autenticidade dos fenômenos da hipnose. Apoio científico foi logo depois dado a esse ponto de vista por Heidenhain, mas não impediu os professores de psiquiatria de declararem por muito tempo que o hipnotismo era não somente fraudulento como também perigoso, e de considerarem os hipnotizadores com desprezo. Em Paris vira o hipnotismo usado livremente como um método para produzir sintomas em pacientes, então removendo-os novamente. Eagora nos chegava a notícia de que surgira uma escola em Nancy que fazia uso extenso e marcantemente bem-sucedido da sugestão, com ou sem hipnotismo, para fins terapêuticos. Ocorreu assim, como algo natural, que, nos primeiros anos de minha atividade como médico, meu principal instrumento de trabalho, afora os métodos psicoterapêuticos aleatórios e não sistemáticos, tenha sido a sugestão hipnótica. (FREUD, 1924. Grifo nosso).
} 
direta da visão de Sloterdijk na Crítica ao tomar o século XX como uma fase tardia e degenerada do Iluminismo" (HERMAN, 1990, p. 109).

O encontro com $A$ árvore mágica deu início a um novo caminho em meu percurso. Alterou-se a paisagem, das ruas de Lisboa na década de 1970, desloquei-me para os campos germânicos e, depois, para Paris e arredores. Voltei para o século XVIII. Não havia mais trem, a viagem, em sua maior parte, era realizada em diligências, mas, devido aos imprevistos que um tipo de viagem como essa está sujeita, alguns trechos foram feitos a pé.

Apropriei-me de um pequeno ambiente literário relativo às doenças nervosas e às técnicas médicas setecentistas de cura. Essas técnicas remontam a Antiguidade, foram reinterpretadas no período medieval, relidas e praticadas por médicos europeus do século XVIII e reformuladas no século XIX pelos mestres de Freud e, também, por ele mesmo. Cada época, no entanto, criou sua maneira própria de ler e trabalhar com tais ensinamentos iniciáticos. Meu percurso levou-me ao século XVIII, portanto, e às suas peculiaridades. Naquele momento a maneira 'própria' de lidar com os fenômenos relativos à saúde e à doença era a maneira 'iluminista' , ou como diria Foucault, a maneira da episteme clássica (FOUCAULT, 2007).

Então li romances, epístolas, mémoires, obras filosóficas, tratados científicos. Muitas dessas sugestões de leitura vinham-me das variadas intertextualidades figuradas no romance de Sloterdijk: referências ao romance dialógico de Denis Diderot intitulado 0 sobrinho de Rameau, às memórias de Teresa filósofa, à peregrinação da princesa de Golovin, personagem da novela homônima de Jacob Wassermann. Pesquisei sobre os personagens históricos que percorrem o teatro mágico de Sloterdijk, como Galliani, Marat, madame de Polignac, Condorcet, Guilhotin, Mesmer, Puységur e Freud. Perambulei pelas ruas de Paris com Jan van Leyden e com os personagens de Balzac. Conheci o Palais Royal: as editoras, as boticas, as casas de prostituição, os cafés e os teatros que por ali ficavam. Avistei o Louvre, passeei pela Place Vendôme, cheguei às Tulherias. Soube das intrigas da corte, fui até Versalhes, participei de salões literários.

E a partir daí pude finalizar a escritura de minha dissertação.

\section{Referências}

ANKERSMITH, Frank R. Historiografia e pós-modernismo. Revista Topoi, Rio de Janeiro, n. 2, p. 113-135, mar./2001. Disponível em:<http://www.ppghis.ifcs.ufrj.br/ media/topoi2a4.pdf>. Acesso em: 2 ago. 2009.

ANTUNES, António Lobo. Memória de elefante. Rio de Janeiro: Objetiva, 2009. 
ARMS, Kate. Polygamy in münster. Starr King School's Unitarian Universalist History class. 2001. Disponível em:<http://www.sksm.edu/research/papers/polygamy.pdf>. Acesso em: 17 abr. 2011.

AUGUSTO, Daniel. Um quiproquó metódico: os romances de Bernardo Carvalho. Trópicos (Revista Online), 2004.2 Disponível em: <http://pphp.uol.com.br/tropico/html/textos/2374,1.shl>. Acesso em: 28 fev. 2011.

BALZAC, Honoré de. Prefácio à "Comédia Humana" . In: Estudos de mulher. Tradução de Ilana Heineberg. Porto Alegre: LP\&M, 2006.

BILANGE, Elizabeth Maria Azevedo. O áspero humor de Lobo Antunes. 2007. 219 f. Tese (Doutorado em Literatura Portuguesa) - Universidade de São Paulo, 2007. Disponível em:<http://www.teses.usp.br/teses/disponiveis/8/8150/tde-13022008-104503/pt-br.php>. Acesso em: 10 fev. 2011.

BLOCH, Marc. A apologia da história ou o ofício do historiador. Tradução de André Telles. Rio de Janeiro: Jorge Zahar, 2001.

BOEHLICH, Walter (Org.). As cartas de Sigmund Freud para Eduard Silberstein (1871-1881). Tradução de Flávio Meurer. Rio de Janeiro: Imago, 1995.

CARVALHO, Bernardo. Nove noites. São Paulo: Companhia das Letras, 2006.

CLASTRES, Pierre. A sociedade contra o Estado. In CLASTRES, Pierre. A sociedade contra 0 Estado. Tradução de Theo Santiago. São Paulo: Cosac \& Naify, 2003. p. 207-234.

DUGNANI, Patrício; CRUZ, Lílian Aparecida. Mitologia e pós-modernidade: Proteu, Argos e Narciso - os mitos e seus reflexos na sociedade. Sistema Anhanguera de Revistas Eletrônicas, Valinhos, v. $1, \quad$ ano $1, \quad 2007 . \quad$ Disponível em: <http://sare.unianhanguera.edu.br/index.php/anudo/article/view/759/586>. Acesso em: 2 fev. 2011.

ELLENBERGER, Henri F. The discovery of the unconscious. the history and evolution of dynamic psychiatry. Washington: BasicBooks, 1970.

FOUCAULT, Michel. As palavras e as coisas. uma arqueologia das ciências humanas. 9. ed. Tradução de Salma Tannus Muchail. São Paulo: Martins Fontes, 2007.

FREUD, Sigmund; SALOMÃO, Jayme (Dir.). Um estudo autobiográfico; inibições, sintomas e ansiedade: a questão da análise leiga e outros trabalhos. Edição Eletrônica de Sigmund Freud. Rio de Janeiro: Imago. [1924]. v. 20. (Obras Psicológicas).

GOETHE, Johann Wolfgang. Os anos de aprendizado de Wilhelm Meister. Tradução de Nicolino Simone Neto. São Paulo: Editora 34, 2006. 
GRUPIONI, Luís Donisete Benzi. Coleções e expedições vigiadas. os etnólogos no Conselho de Fiscalização das expedições artísticas e científicas no Brasil. São Paulo: Hucitec/Anpoc, 1998.

HERMAN, Luc. The relevance of History: Der Zauberbaum (1985) by Peter Sloterdijk and Hawksmoor (1985) by Peter Ackroyd. In: D' HAEN, Theo; BERTENS, Hans. History and postwar writing. Amsterdam: Rodopi; Antwerpen: Restant, 1990. p. 107-124.

HUTCHEON, Linda. Poética do pós-modernismo: história, teoria e ficção. Tradução de Ricardo Cruz. Rio de Janeiro: Imago, 1991.

MUITO estrago por nada: o bug do milênio causará problemas no serviço público, nas comunicações e até mesmo na economia mundial. Isto É, São Paulo, n.1577, 22. dez. 1999. Disponível em: <http://www.istoe.com.br/reportagens/27774_muito+estrago+ por+ nada+>. Acesso em: 31 jul. 2009.

PRIBERAM. Dicionário Priberam da Língua Portuguesa. 2012. Disponível em:<http://www.priberam.pt/dlpo/>. Acesso em: 15 jan. 2013.

RANUM, Orest. Os refúgios da intimidade. In: CHARTIER, Roger. História da vida privada: da renascença ao século das luzes. Tradução de Denise Bottman e Bernardo Joffily. São Paulo: Companhia das Letras, 1991. p. 211-262.

RUBIÃO, Murilo. O coelhinho Teleco. In: COSTA, Flávio Moreira da (Org.). Os melhores contos fantásticos. Tradução de Adriana Lisboa. Rio de Janeiro: Nova Fronteira, 2006. p. 683-689.

SILVA, Haidê. A metaficção historiográfica no romance "Os cus de Judas" . 2007. 148 f. Tese (Doutorado em Literatura Portuguesa) - Universidade de São Paulo, São Paulo. Disponível em:<http://www.teses.usp.br/teses/disponiveis/8/8150/tde-13022008-105213/pt-br.php>.

Acesso em: 9 fev. 2011.

SLOTERDIJK, Peter. $A$ árvore mágica: o surgimento da psicanálise no ano de 1785 . Tentativa épica com relação à filosofia da psicologia. Rio de Janeiro: LTC, 1988.

VASCONCELOS, José Antonio. Quem tem medo de teoria: a ameaça do pós-modernismo na historiografia americana. São Paulo: Annablume: Fapesp, 2005.

WERNET, Augustin. Goethe e Luden: um diálogo sobre a história. Revista Ciência e Filosofia, São Paulo, n. 2, p. 141-153, 1980.

WHITE, Hayden. O fardo da história. In: WHITE, Hayden. Trópicos do discurso: ensaios sobre a crítica da cultura. Tradução de Alípio Correia de França Neto. São Paulo: Edusp, 1994a. p. 39-63. 
WHITE, Hayden. O texto histórico como artefato literário. In: WHITE, Hayden. Trópicos do discurso: ensaios sobre a crítica da cultura. Tradução de Alípio Correia de França Neto. São Paulo: Edusp, 1994b. p. 97-116.

ZWEIG, Stefan. A cura pelo espírito: Mesmer, Mary Baker-Eddy, Freud. Tradução de Cândido de Carvalho. Rio de Janeiro: Guanabara, [1930]. 